\title{
The Trypanosoma cruzi Genome Project: Nuclear Karyotype and Gene Mapping of Clone CL Brener
}

\author{
Marcia RM Santos, Maria I Cano, Alejandro Schijman*, Hernan Lorenzi*, \\ Martin Vázquez*, Mariano J Levin*, José Luis Ramirez**, Adeílton

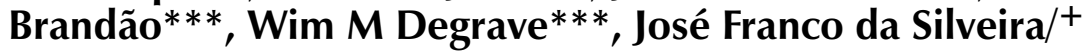

\author{
Universidade Federal de São Paulo (UNIFESP-EPM), Rua Botucatu 862, 04023-062, São Paulo, SP, Brasil \\ *Instituto de Investigaciones en Ingenieria Genetica y Biologia Molecular, INGEBI-CONICET, FCEyN-UBA, \\ Obligado 2490, 1428 Buenos Aires, Argentina **Universidad Central de Venezuela, Caracas, Venezuela \\ ***Instituto Oswaldo Cruz, Av. Brasil 4365, 21045-900, Rio de Janeiro, RJ, Brasil
}

By using improved pulsed field gel electrophoresis conditions, the molecular karyotype of the reference clone CL Brener selected for Trypanosoma cruzi genome project was established. A total of 20 uniform chromosomal bands ranging in size from 0.45 to 3.5 Megabase pairs (Mbp) were resolved in a single run. The weighted sum of the chromosomal bands was approximately $87 \mathrm{Mbp}$. Chromoblots were hybridized with 39 different homologous probes, 13 of which identified single chromosomes. Several markers showed linkage and four different linkage groups were identified, each comprising two markers. Densitometric analysis suggests that most of the chromosomal bands contain two or more chromosomes representing either homologous chromosomes and/or heterologous chromosomes with similar sizes.

Key words: Trypanosoma cruzi - clone CL Brener - genome project - molecular karyotype - chromosome mapping - genetic map

The establishment of the molecular karyotype of Trypanosoma cruzi is an essential part of the genome project of this parasite, particulary in the construction of detailed physical and genetic maps. This review focuses on the nuclear karyotype analysis and gene mapping of the reference clone CL Brener selected for the T. cruzi genome project. We have also included in this article some of the noteworthy features that can be found in the genome of this parasite.

\section{SIZE AND ORGANIZATION OF THE T. CRUZI GENOME}

The genome size of $T$. cruzi has been estimated by different procedures (renaturation kinetic analysis, microfluorometry, flow cytometry, chemical analysis, molecular karyotyping). A striking fea-

Financial support from CYTED-Subprogram of Biotechnology (Spain), FAPESP (Brazil), CNPq/PADCT (Brazil), Centro Brasileiro Argentino de Biotecnologia (CBAB/CABBIO), UNDP/World Bank/WHO Special Programme for Research and Training in Tropical Diseases, Fundacion Antorchas, CYT-UBA-EX203-283, PIA-1997-CONICET.

${ }^{+}$Corresponding author. Fax: +55-11-571.1095. E-mail: franco.dmip@epm.br

Received 20 August 1997

Accepted 10 September 1997 ture of $T$. cruzi is that the total DNA content per cell varies among different strains, isolates and among clones derived from the same strain (Castro et al. 1981, Lanar et al. 1981, Dvorak et al. 1982, Kooy et al. 1989, Thompson \& Dvorak 1989, McDaniel \& Dvorak 1993). In the renaturation studies, the complexity of the T. cruzi genome was estimated to be $1.8-2.5 \times 10^{8}$ base pairs (bp) (Castro et al. 1981, Lanar et al. 1981). The absolute amount of total DNA (nuclear+kinetoplast) varies from 0.12 to 0.33 pg per cell among different strains and among clones isolated from the same strain (Lanar et al. 1981, Kooy et al. 1989, Thompson \& Dvorak 1989, McDaniel \& Dvorak 1993).

\section{REPETITIVE DNA SEQUENCES}

The genome of $T$. cruzi, like that of many other eukaryotic organisms, is composed by three major classes of DNA sequences: (a) protein-coding DNA (single copy genes; duplicated and diverged gene families); (b) tandemly repeated DNA (genes encoding RNAs and proteins, e.g., rRNA, medRNA, histone, trans-sialidase, tubulin, amastin, etc); (c) repetitious DNA (micro and minisatellites, short and long interspersed elements, SINE-like DNA sequences, retroposons, retrotransposons, etc). In addition to these sequences, spacer or connecting DNA sequences can be found between genes encoding proteins or RNAs. 
Reassociation kinetics studies of the T. cruzi DNA have shown that the highly and middle repetitive sequences account for about $44 \%$ of the genome of this parasite (Castro et al. 1981, Lanar et al. 1981). For instance, a highly repetitive, tandemly organized minisatellite DNA sequence (195 base pairs long, 120000 copies/genome) and an interspersed repetitive element, named E13 (1 025 bp long, 10000 copies/genome), account for $9 \%$ and $7 \%$ of the total DNA of the parasite (Sloof et al. 1983, Gonzalez et al. 1984, Requena et al. 1992). In addition to these sequences, two other highly repeated interspersed DNA sequences, called E12 (1 123 bp long, 5000 copies/genome) and E22 (7 000 copies/genome) were isolated from the nuclear DNA (Requena et al. 1993, 1994, 1996).

Several short interspersed middle repeated DNA sequences have been found in the T. cruzi genome: SIRE (428 bp long, 2000 copies/genome), SRE (40-120 bp long, 400-900 copies/genome) and RLE (317 bp long). These sequences show several features of retroposon-like elements such as the insertion in different loci and flanked by short direct repeats, and the presence of a short A-rich tail at the end of the repeat (Kendall et al. 1990, Novak et al. 1993, Vazquez et al. 1994).

Retrotransposon like-sequences have been also described in the T. cruzi genome. These sequences are about 6 kilobase pairs (Kbp) long, share gene homologies and structural features with retrovirus and contain open reading frames encoding enzymes which could be involved in their own transposition. For example, a site-specific retrotransposon (siteposon) called CZAR (6.0 Kbp long), was identified in the miniexon gene repeat region of $T$. cruzi (Aksoy 1991). Another retrotransposon, called L1Tc or B11 element (5.0 Kbp long, 2000 copies/ genome), was found to be distributed in the T. cruzi genome. Sequences homologous to reverse transcriptase have been also detected in the L1Tc retrotransposon (Martin et al. 1995, Gruber 1995).

\section{GENE ORGANIZATION: SINGLE COPY GENES, MULTICOPY GENE FAMILIES}

Many trypanosome genes encoding housekeeping proteins, antigens, enzymes and structural proteins are arranged as allelic tandem repeats. Tandem arrangement has been described for genes encoding RNA polymerases, actin, Hsp70, glycolytic enzymes, histones, cysteine proteases, tubulin, ribosomal proteins, ubiquitin and repetitive antigens (Michels et al. 1990). There is some correlation between the copy number of a gene and the amount of its product in the cell. Highly abundant proteins and RNAs (e.g., tubulin, Hsp70, cysteine protease, histones, medRNA, rRNA) are en- coded by multiple copy genes.

The infective forms of $T$. cruzi express stagespecific surface antigens which are involved in the parasite entry into the host cell. Several genes for surface antigens display homology among them and can be grouped in a superfamily designated as the gp85/sialidase multigene family (Takle \& Cross 1991, Campetella et al. 1992, Cross \& Takle 1993, Colli 1993, Franco et al. 1993, Araya et al. 1994).

There is a tendency for the clustering of unrelated genes in certain parts of the genome of trypanosomes. Evidences indicate that the array of genes are multi-cistronic transcription units whose transcripts are processed by trans-splicing (Michels et al. 1990). It has been suggested that gene duplication and the clustering of various genes in multicistronic transcription units could be a common means by which trypanosomes regulate protein levels.

\section{SEPARATION OF CHROMOSOMES BY PULSED FIELD GEL ELECTROPHORESIS}

The genetic material of $T$. cruzi is organized in small chromosomes which poorly condensate during the cell division; therefore its analysis by conventional cytogenetic techniques is not possible. The development of pulsed field gel electrophoresis (PFGE) techniques has allowed the separation of intact chromosomes of lower eukaryotes, including $T$. cruzi.

Size fractionation of chromosomal bands by PFGE and hybridization to different DNA probes have been used to establish the molecular karyotype of several strains and clones of T. cruzi. The nuclear genome of the $T$. cruzi is of a highly plastic nature, as observed by PFGE. The sizes and number of chromosomal bands vary among strains and clones of this parasite (Gibson \& Miles 1986, Engman et al. 1987, Aymerich \& Goldenberg 1989, Henriksson et al. 1990, 1993, 1995, 1996, Wagner \& So 1990, Cano et al. 1995).

\section{ELECTROKARYOTYPE OF CLONE CL BRENER}

In our laboratory, we have established a protocol that allows a good separation of the chromosomal bands ranging from $0.45 \mathrm{Mbp}$ to $4.0 \mathrm{Mbp}$. The running, which takes $132 \mathrm{hr}$, is done in a Gene Navigator apparatus (Pharmacia) in $1.2 \%$ agarose gel with $0.5 \mathrm{x}$ (times) TBE (45 mM Tris $/ 45 \mathrm{mM}$ boric acid/1 mM EDTA, pH 8.3) (Cano et al. 1995). We have used five phases of homogeneous pulses with interpolation for $132 \mathrm{hr}$ at 80 volts at $13 \mathrm{de}$ grees Celsius.

The molecular karyotype obtained with this procedure is shown in Figure. The chromosomal profile is very complex with 20 chromosomal bands ranging from $0.45 \mathrm{Mbp}$ to $3.5 \mathrm{Mbp}$ : 12 megabase 


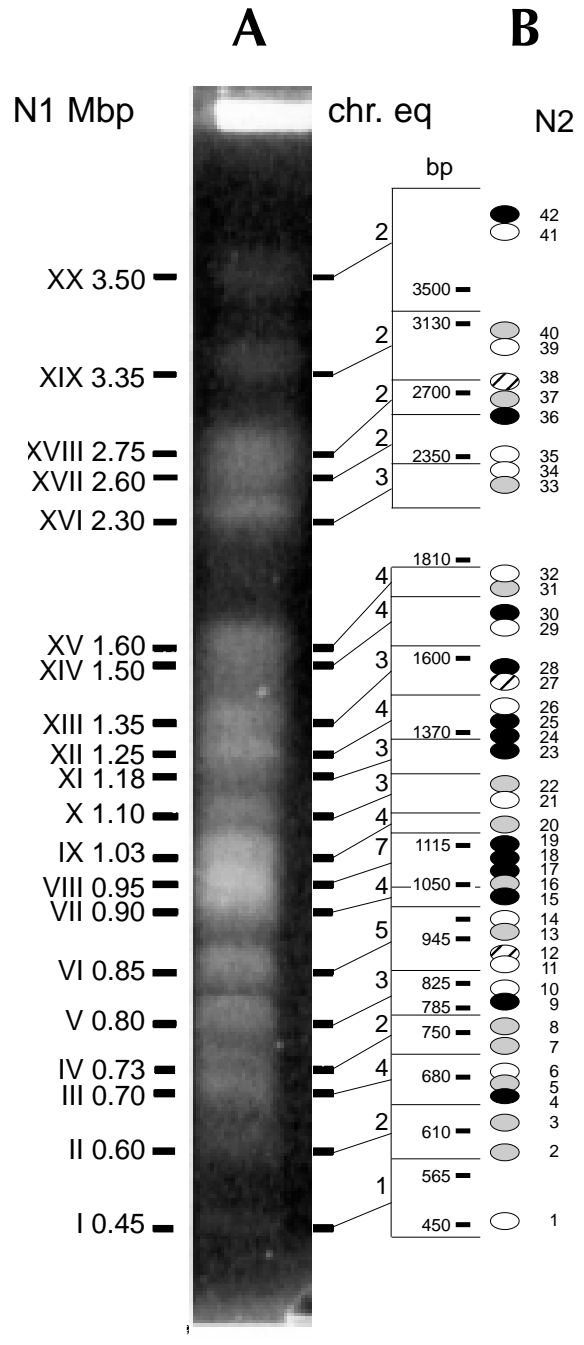

Molecular karyotype of clone CL Brener. Comparison of the data from Cano et al. (1995) (Panel A) and Henriksson et al. (1995) (Panel B). Panel A: ethidium bromide-stained pattern (Et Br) of chromosomal bands after separation by PFGE. The sizes (Mbp) and the numbers of the chromosomal bands are indicated in roman and arabic numerals on the left of the figure. Chromosome equivalents of each band are indicated on the right. Panel B: schematic karyotype based on several experiments using different separation conditions and hybridization with chromosomal markers (Henriksson et al. 1995, 1996). The sizes (bp) and the numbers of the chromosomal bands are indicated on the left and the right of the figure, respectively. Some of the bands were not resolved after EtBr staining and were identified only by hybridization with specific probes (Henriksson et al. 1995).

bands ranging from 3.5 to $1.0 \mathrm{Mbp}$ and eight intermediate chromosomal bands ranging from 0.45 Mbp to $1.0 \mathrm{Mbp}$. The distribution of the ethidium bromide fluorescence is not the same for all chromosomal bands indicating the existence in a same band of two or more homologous chromosomes or the existence of heterologous chromosomes with the same size (aneuplody).
In order to estimate the number of chromosomes per band, we have hybridized the chromoblot with a probe containing the telomeric repetition of T. brucei (Van der Ploeg et al. 1984). There is a good correlation between the fluorescence pattern and the hybridization profile obtained with the telomeric probe. We have scanned the autoradiogram and the relative area of the smaller band (band I) was chosen arbitrarily as standard for minimal ploidy. The number of chromosomes per band, defined here as chromosome equivalent, was estimated dividing the densitometric value obtained of the area of each band by the area of band I.

With this approximation, we estimated that there are 64 chromosomes per cell (epimastigote). It is important to note that this is a rough estimation and it cannot be taken as definitive, since (i) the exact number of chromosomes in band I (our standard for minimal ploidy) is not known; (ii) the exact distribution of the sequences homologous to T. brucei telomeric sequences within the chromosomes is not known. Thus, our results suggest that most of the chromosomal bands contain two or more chromosomes representing homologous chromosomes and/or heterologous chromosomes with similar sizes.

To estimate the genome complexity of clone CL Brener, the chromosome equivalent of each band was multiplied by its corresponding molecular size. By summing up these values, the total nuclear DNA content was estimated to be $87 \mathrm{Mbp}$, whereas the genome size determined by microfluorometry was estimated at approximately 100 Mbp. This result corroborates the hypothesis that T. cruzi is an aneuploid organism.

\section{LOCATION OF T. CRUZI CLONED SEQUENCES ON CHROMOSOMAL BANDS OF CLONE CL BRENER}

We have hybridized the chromoblots of clone CL Brener with a panel of cloned sequences (repetitive sequences, polymorphic sequences, genes encoding proteins and structural RNAs, anonymous sequences) (Table I). Table II compiles the chromosomal location of 39 T. cruzi homologous sequences.

Several repetitive sequences were mapped on all chromosomal bands such as SIRE and C6 (middle repetitive sequences which resemble retroposon-like sequences). Other repetitive sequences can be found in most of the chromosomal bands (for instance, B11, 196 bp satellite, SRE). It is interesting to analyse the chromosomal distribution of the genes encoding surface antigens of the parasite's infective forms. For instance, genes encoding trypomastigote surface antigens (gp90, gp82 and gp85) could be mapped on the majority 
TABLE I

Chromosomal markers $^{a}$

\begin{tabular}{|c|c|c|c|}
\hline Locus & $\begin{array}{c}\text { Genbank Accession } \\
\text { Number }\end{array}$ & Function & Reference \\
\hline C6 & U16295 & Interspersed repetitive element & Araya et al. in press \\
\hline SIRE & X75033 & Short interspersed repetitive element & Vazquez et al. (1994) \\
\hline Minisatellite & K00393 & Satellite repetitive element & Gonzalez et al. (1984) \\
\hline Gp 82 & L14824 & $82 \mathrm{kDa}$ surface antigen & Araya et al. (1994) \\
\hline Gp 85 & J04667 & $85 \mathrm{kDa}$ surface antigen & Takle \& Cross (1991) \\
\hline Gp 90 & L11287 & $90 \mathrm{kDa}$ surface antigen & Franco et al. (1993) \\
\hline $\mathrm{TcP} 2 \beta$ & X52323 & Ribosomal protein $\mathrm{P} 2 \beta$ & Schijman \& Levin (1992) \\
\hline B11 & $\mathrm{U} 15615$ & Retrotransposon-like element & Gruber (1995) \\
\hline $1 F 8$ & X02838 & Calcium-binding protein & Gonzalez et al. (1990) \\
\hline H49 & L09564 & Flagellar repetitive antigen & Cotrim et al. (1995) \\
\hline CRA & J04016 & Cytoplasmic repetitive antigen & Lafaille et al. (1989) \\
\hline SZ5 & X83599 & Non Repetitive SIRE Associated Sequence & Vazquez et al. (1996) \\
\hline SL-RNA & K02632 & Spliced leader sequence & Gonzalez et al. (1990) \\
\hline Hsp 60 & X67473 & $60 \mathrm{kDa}$ heat shock protein & Rondinelli et al. unpubl. \\
\hline Hsp 70 & X07083 & $70 \mathrm{kDa}$ heat shock protein & Rondinelli et al. unpubl. \\
\hline B12 & L07759 & $230 \mathrm{kDa}$ repetitive antigen & Gruber \& Zingales (1993) \\
\hline B13 & U15616 & $140 / 116 \mathrm{kDa}$ repetitive antigen & Gruber \& Zingales (1993) \\
\hline$\alpha$ and $\beta$ Tubulins & & $\alpha$ and $\beta$ Tubulins & Rondinelli et al. (1986) \\
\hline Ubiquitin & J03945 & Ubiquitin & Slezynger et al. unpubl. \\
\hline Actin & U20234 & Actin & Rondinelli et al. unpubl. \\
\hline MIP & X69655 & Peptidyl-prolyl cis-trans isomerase & Moro et al. (1995) \\
\hline KAP & M25364 & Kinetoplast-associated protein & Gonzalez et al. (1990) \\
\hline 24S $\alpha \mathrm{rDNA}$ & M28885 & $24 \mathrm{~S} \alpha \mathrm{rRNA}$ & Arruda et al. (1990) \\
\hline $24 \mathrm{~S} \beta$ rDNA & & $24 \mathrm{~S} \beta$ rDNA & Novak et al. (1993) \\
\hline Amastin & U04337 a 04341 & Amastigote stage-specific antigen & Teixeira et al. (1994) \\
\hline $\mathrm{Tc} 40$ & U24190 & $90 \mathrm{kDa}$ cytoplasmic antigen & Lenesechal et al. (1997) \\
\hline Cruzipain & M90067 & Cysteine protease & Lima et al. (1994) \\
\hline C11 & & $90 \mathrm{kDa}$ surface antigen & Cummings (1989) \\
\hline SRE & M63895 & Spacer Repetitive Element & Novak et al. (1993) \\
\hline cDNA 68 & & Unknown Open Reading Frame (ORF) & Santos et al. unpubl. \\
\hline cDNA 78 & & $\gamma$ elongation factor & Santos et al. unpubl. \\
\hline cDNA 40 & & Unknown ORF & Santos et al. unpubl. \\
\hline cDNA 51 & & Unknown ORF & Santos et al. unpubl. \\
\hline SZ 23-14 & & Short interspersed repetitive element & Vazquez et al. (1996) \\
\hline SZ 7-39 & & Short interspersed repetitive element & Vazquez et al. (1996) \\
\hline SZ 39 & & Short interspersed repetitive element & Vazquez et al. (1996) \\
\hline SZ 32 & & Short interspersed repetitive element & Vazquez et al. (1996) \\
\hline SZ 7-32 & & Short interspersed repetitive element & Vazquez et al. (1996) \\
\hline
\end{tabular}

$a$ : an additional list of chromosomal markers used in Trypanosoma cruzi genome project can be found in Henriksson et al. (1995).

of the chromosomal bands. On the other hand, genes encoding trans-sialidase or SAPA, which displays homology with these genes and therefore belongs to the superfamily of trans-sialidases, were mapped on two chromosomal bands (Egima et al. 1996).

Some genes have an unique chromosomal location and can be used as specific markers for these chromosomes. Several markers, such as a repetitive flagellar antigen (H49), a cytoplasmic repetitive antigen (CRA), Hsp70 and KAP were mapped on neighboring chromosomal bands, which may represent size-polymorphic homologous chromosomes.
As discussed above, the non-stoichiometric staining of chromosomal bands by ethidium bromide suggests the existence of size-identical heterologous chromosomes. Gene mapping data corroborate the evidences of aneuploidy for the chromosomal bands which are poorly resolved in PFGE.

Evidences obtained in our laboratory suggest that bands XVI and XVII could carry a pair of sizepolymorphic homologous chromosomes which are defined by the genes encoding the repetitive antigens H49 and CRA (Santos MRM, unpublished results). It is noteworthy that several genetic markers (spliced leader sequence, gp90, gp82, cDNA 
TABLE II

Localization of repetitive sequences, genes encoding proteins and structural RNAs and anonymous markers on chromosomal bands of clone CL Brener

\begin{tabular}{|c|c|c|c|c|c|}
\hline $\begin{array}{l}\text { Band } \\
\text { No. }\end{array}$ & $\begin{array}{l}\text { Size } \\
\text { Mbp }\end{array}$ & Repetitive sequence & Multigenic family & $\begin{array}{l}\text { Protein, unknown ORF } \\
\text { Structural RNA }\end{array}$ & $\begin{array}{l}\text { Anonymous } \\
\text { marker }\end{array}$ \\
\hline XX & 3.50 & C6, Sire, Sat. & & Hsp6O & \\
\hline XIX & 3.35 & C6, Sire, Sat., SRE, B11 & & Amastin, cDNA68 & SZ23-14 \\
\hline XVIII & 2.75 & C6, Sire, Sat., SRE & gp82, gp90, gр85 & C11, Ubiquitin, cDNA78 & SZ23-14 \\
\hline XVII & 2.60 & C6, Sire, Sat., SRE & gp85 & CRA, H49, cDNA68, cDNA78 & SZ23-14 \\
\hline XVI & 2.30 & C6, Sire, Sat., SRE, B11 & gp82, gp90, gp85 & CRA, H49, cDNA40, cDNA78, SL & L Z23-14 \\
\hline $\mathrm{XV}$ & 1.60 & C6, Sire, Sat., SRE, B11 & gp82, gp90, gp $85, \mathrm{P} 2 \beta$ & Amastin, $\alpha$ tubulin & SZ7-39 \\
\hline XIV & 1.50 & C6, Sire, Sat., B11 & $\mathrm{P} 2 \beta$ & 18/24S rDNA & \\
\hline XIII & 1.35 & C6, Sire, SRE & & B12, B13, cDNA51, cDNA57 & SZ23-14 \\
\hline XII & 1.25 & C6, Sire, B11 & gp82, gp90, gp85, Р2 $\beta$ & cDNA51 & SZ39 \\
\hline XI & 1.18 & C6, Sire & & & \\
\hline $\mathrm{X}$ & 1.10 & C6, Sire, SRE, B11 & gp82, gp90, gp85, Р2 $\beta$ & Hsp70 & SZ39 \\
\hline IX & 1.03 & C6, Sire, B11 & gp82, gp90, gp85, Р2 $\beta$ & MIP, Hsp70 & \\
\hline VIII & 0.95 & C6, Sire, Sat. & gp82, gp90, gр85 & KAP & SZ5 \\
\hline VII & 0.90 & C6, Sire, SRE & & & SZ7-32 \\
\hline VI & 0.85 & C6, Sire & gp82, gp90 & KAP, Actin, Cruzipain & SZ32 \\
\hline $\mathrm{V}$ & 0.80 & C6, Sire, Sat., SRE & gp82, gр90, gр85 & 1F8, SL, Tc40, cDNA40 & \\
\hline IV & 0.73 & C6, Sire & gp85 & & \\
\hline III & 0.70 & C6, Sire, SRE & gp82, gp90 & Tc40 & SZ5 \\
\hline II & 0.60 & C6, Sire & gp85 & 1F8, Cruzipain & SZ39 \\
\hline I & 0.45 & C6, Sire & gp85 & & \\
\hline
\end{tabular}

40, B11) mapped on band XVI are absent in band XVII. On the other hand, cDNA 68 which was mapped on band XVII is absent in band XVI. We could explain these results by the existence of more than two different homologous chromosomes in bands XVI and XVII. In fact, the chromosome equivalent data suggest the existence of two or three chromosomes in these bands.

\section{IDENTIFICATION OF GENETIC LINKAGE GROUPS}

Several markers were mapped on the same chromosomal bands suggesting that they could be linked. For example, genes encoding antigens B12 and B13 were mapped on the chromosomal band XIII and the hybridization patterns of gp 82 and gp90 genes are very similar. The physical linkage between these genes, B12 and B13 or gp 82 and gp90, was demonstrated by isolation of genomic recombinant clones carrying linked copies of B12 and B13 or gp90 and gp82 (Gruber 1995, Cano 1995).

Henriksson et al. (1995) identified nine different linkage groups, each comprising 2-4 markers. The linkage between the markers was maintained in eight of the nine linkage groups when a panel comprising 26 different $T$. cruzi strains were analyzed. This information will be very useful for the construction of physical chromosomal maps required for the $T$. cruzi genome project.

\section{COMPARISON THE MOLECULAR KARYOTYPE OF CL BRENER CLONE OBTAINED BY DIFFERENT GROUPS}

The molecular karyotype of clone CL Brener was also determined using several different run conditions (Henriksson et al. 1995, 1996) (see Fig.). General speaking there is a reasonable correlation between the results of Cano et al. (1995) and those from the Henriksson and co-workers. Several genes were mapped on the same chromosomal bands by both groups. For instance, the genes encoding the antigens H49 (also designed as JL7, FRA, Tc1), CRA (Tc30, JL8, Tc27), B13 (Tc2) and ubiquitin. Four linkage groups found in our laboratory were also reported by Henriksson and co-workers.

Both groups mapped genes Hsp70, SAPA, cruzipain and 1F8 on two chromosomal bands. But, there are small differences in the sizes of the chromosomes recognized by these probes. For instance, we have mapped the 1F8 on two bands of 0.80 and $0.60 \mathrm{Mbp}$ whereas Henriksson et al. (1995) mapped this marker on two bands of 1.15 and $0.875 \mathrm{Mbp}$.

There is a discrepancy between the number of chromosomes estimated by PFGE and the number of kinetochores. Data obtained in the electrokaryotypes suggest that at least most of the chromosomal bands are diploid and the maximal number of chromosomes was estimated as 64 (Cano et al. 1995) or 80 (Henriksson et al. 1995). Three-dimensional 
reconstructions from electron micrographs of serial sections of mitotic nuclei in trypanosomes showed the existence of ten dense plaques which are putative kinetochores (Solari 1980a,b, 1995). Among the trypanosomatids the number of dense plaques is lower than the number of chromosomal bands visualized by PFGE. In contrast, other parasite protozoans and yeast present a good correlation between the number of dense plaques and the chromosome-sized DNA molecules. The reason for the difference in the number of dense plaques and the bands in the electrokaryotypes of trypanosomes is not known.

\section{IDENTIFICATION OF ESTs (EXPRESSED SITE TAG) USING ISOLATED CHROMOSOMES}

Chromosomal bands were isolated from preparative gels, labeled by random priming and used as probes in the screening of an epimastigote cDNA library (Urmenyi et al. 1996). Several cDNA clones were isolated with this procedure (Table II). For instance, we have isolated more than ten cDNA clones using DNA from band XVI as a probe. Clone 78 (Elongation Factor 1g) hybridizes with several chromosomal bands including the XVI and XVII bands. Specific chromosome markers were also isolated by this procedure such as clone 67 which is specific for chromosome XIII. This procedure can thus be very useful to identify ESTs specific for chromosomes.

\section{ACKNOWLEDGMENTS}

To Dr Rafael Rangel Aldao for help and encouragement. To Drs Angela Cruz and Thelma Slezynger, and Prof. George Cross for providing us the following probes: T. brucei telomeric probe, ubiquitin and gp 85 , respectively.

\section{REFERENCES}

Aksoy S 1991. Site-specific retrotransposons of the Trypanosomatid protozoa. Parasitol Today 7: 281285.

Araya J, Cano IM, Gomes HBM, Novak EM, Requena JM, Alonso C, Levin JM, Guevara P, Ramirez JL, Franco da Silveira J 1997. Characterization of an interpersed repetitive DNA element in the genome of Trypanosoma cruzi. Parasitology (in press).

Araya JE, Cano MI, Yoshida N, Franco da Silveira J 1994. Cloning and characterization of a gene for the stage-specific 82-kDa surface antigen of metacyclic trypomastigotes of Trypanosoma cruzi. Mol Biochem Parasitol 65: 161-169.

Arruda MV, Reinach FC, Colli W, Zingales B 1990. Sequence of the $24 \alpha$ ribossomal gene and characterization of a corresponding pseudogene from Trypanosoma cruzi. Mol Biochem Parasitol 40: 35-42.

Aymerich S, Goldenberg S 1989. The karyotype of Trypanosoma cruzi Dm 28c: comparison with other $T$. cruzi strains and trypanosomatids. Exp Parasitol 69: 107-115.
Campetella O, Sanchez D, Cazzulo JJ, Frasch ACC 1992. A superfamily of Trypanosoma cruzi surface antigens. Parasitol Today 8: 378-381

Cano MI 1995. Análise do genoma do Trypanosoma cruzi: Mapeamento cromosomal e caracterização genômica de uma família que codifica antígenos de superfície específicos das formas tripomastigotas metaciclicas (MTS-GP90). PhD Thesis, Escola Paulista de Medicina, São Paulo, 163 pp.

Cano MI, Gruber A, Vazquez M, Cortés A, Levin MJ, Gonzalez A, Degrave W, Rondinelli E, Ramirez JL, Alonso C, Requena JM, Franco da Silveira J 1995. Molecular karyotype of clone CL Brener chosen for the Trypanosoma cruzi genome project. Mol Biochem Parasitol 71: 273-278.

Castro C, Craig SP, Castaneda M 1981. Genomic organization and ploidy number in T. cruzi. Mol Biochem Parasitol 4: 273-282.

Colli W 1993. Trans-sialidase: a unique enzyme activity discovered in the protozoan Trypanosoma cruzi. FASEB J 7: 1257-1264.

Cotrim PC, Paranhos-Baccala G, Santos MR, Mortensen C, Cano MI, Jolivet M, Camargo ME, Mortara RA, Franco da Silveira J 1995. Organization and expression of the gene encoding animmunodominant repetitive antigen associated to the cytoskeleton of Trypanosoma cruzi. Mol Biochem Parasitol 71: 89-98.

Cross GAM, Takle GB 1993. The surface trans-sialidase family of Trypanosoma cruzi. Ann Rev Microbiol 46: 385-411.

Cummings LM 1989. Análise da expressão gênica em Trypanosoma cruzi: caracterização de mRNAs e clonagem de genes que codificam para sequências transcritas em diferentes estágios evolutivos do parasita. PhD Thesis, Escola Paulista de Medicina, São Paulo, 216 pp.

Dvorak JA, Hall TE, Crane MSJ, Engel JC, McDaniel JP, Uriegas R 1982. Trypanosoma cruzi: Flow cytometric analysis. I. Analysis of total DNA/organism by means of mitramycin-induced fluorescence. J Protozool 29: 430-437.

Egima CM, Briones MRS, Freitas Junior LHG, Schenkman RPF, Uemura H, Schenkman S 1996. Organization of trans-sialidase genes in Trypanosoma cruzi. Mol Biochem Parasitol 77: 115-125.

Engman DM, Reddy LV, Donelson JE, Kirchhoff LV 1987. Trypanosoma cruzi exhibits inter- and intrastrain heterogeneity in karyotype and chromosomal gene location. Mol Biochem Parasitol 22: 115-123.

Franco FRS, Paranhos-Baccalla G, Yamauchi LM, Yoshida N, Franco da Silveira J 1993. Characterization of a cDNA clone encoding the carboxy-terminal domain of a 90-kilodalton surface antigen of Trypanosoma cruzi metacyclic trypomastigotes. Infect Immun 61: 4196-4201.

Gibson WC, Miles MA 1986. The karyotype and ploidy of Trypanosoma cruzi. EMBO J 5: 1299-1305.

González A, Prediger E, Huecas ME, Nogueira N, Lizardi P 1984. Minichromosomal repetitive DNA in Trypanosoma cruzi: its use in a high-sensitivity parasite detection assay. Proc Natl Acad Sci USA 81: 3356-3360. 
González A, Rosales JL, Ley V, Diaz C 1990. Cloning and characterization of a gene coding for a protein (KAP) associated with the kinetoplast of epimastigotes and amastigotes of Trypanosoma cruzi. Mol Biochem Parasitol 40: 233-243.

Gruber A 1995. Caracterização de dois genes contíguos de Trypanosoma cruzi que codificam antígenos com repetições de epitopos imunodominantes. $\mathrm{PhD}$ Thesis, Universidade São Paulo, São Paulo, 205 pp.

Gruber A, Zingales B 1993. Trypanosoma cruzi: characterization of two recombinant antigens with potential application in the diagnosis of Chagas' disease. Exp Parasitol 76: 1-12.

Henriksson J, Aslund L, Macina RA, Franke de Cazzulo BM, Cazzulo JJ, Frasch ACC, Pettersson U 1990. Chromosomal localization of seven cloned antigen genes provides evidence of diploidy and further demonstration of karyotype variability in Trypanosoma cruzi. Mol Biochem Parasitol 42: 213-224.

Henriksson J, Pettersson U, Solari A 1993. Trypanosoma cruzi: Correlation between karyotype variability and isoenzyme classification. Exp Parasitol 77: 334-348.

Henriksson J, Porcel B, Rydaker M, Ruiz A, Sabaj V, Galanti N, Cazzulo JJ, Frasch ACC, Pettersson U 1995. Chromosome specific markers reveal conserved linkage groups in spite of extensive chromosomal size variation in Trypanosoma cruzi. Mol Biochem Parasitol 73: 63-74.

Henriksson J, Aslund L, Petterson U 1996. Karyotype variability in Trypanosoma cruzi. Parasitol Today 12: 108-114.

Kendall G, Wildespirn AF, Ashall F, Miles MA, Kelly JM 1990. Trypanosoma cruzi glyceraldehyde-3phosphate dehydrogenase does not conform to the "hot spot" topogenic signal model. EMBO J 9: 27512758.

Kooy RF, Ashall F, Van der Ploeg M, Overdulve JP 1989. On the DNA content of Trypanosoma cruzi. Mol Biochem Parasitol 36: 73-76.

Lanar DE, Levy SC, Manning JE 1981. Complexity and content of the DNA and RNA in Trypanosoma cruzi. Mol Biochem Parasitol 3: 327-341.

Lesénéchal M, Duret L, Cano MI, Mortara RA, Jolivet M, Camargo ME, Franco da Silveira J, ParanhosBaccala G 1997. Cloning and characterization of a gene encoding anovel antigen of Trypanosoma cruzi. Mol Biochem Parasitol (in press).

Lima AP, Tessier DC, Thomas DY, Scharfstein J, Storer AC, Vernet T 1994. Identification of new cystein protease gene isoforms in Trypanosoma cruzi. Mol Biochem Parasitol 67: 333-338.

Mac Daniel JP, Dvorak JA 1993. Identification, isolation, and characterization of naturally-occurring Trypanosoma cruzi variants. Mol Biochem Parasitol 57: 213-222.

Martin F, Marañon C, Olivares M, Alonso C, Lopez MC 1995. Characterization of a non-long terminal repeat retrotransposon cDNA (L1Tc) from Trypanosoma cruzi: homology of the first ORF with the Ape family of DNA repair enzymes. J Mol Biol 247: 49-59.

Michels PAM, Hannaert V, Ernest I, Allert S 1990. Organization, structure and evolutionary aspects of genes in Trypanosoma cruzi. Biochem Trypanosomes 18: 727-729.

Moro A, Ruiz-Cabello F, Fernandez-Cano A, Stock RP, González A 1995. Secretion by Trypanosoma cruzi of a peptidyl-prolyl cis-trans isomerase involved in cell infection. EMBO J 14: 2483-2490

Novak E, de Mello M, Gomes HB, Guevara P, Ramirez JL, Franco da Silveira J 1993. Repetitive sequences in the ribosomal intergenic spacer of Trypanosoma cruzi. Mol Biochem Parasitol 60: 273-280.

Requena J, Martin F, Soto M, Lopez MC, Alonso C 1994. Characterization of a short interspersed reiterated DNA sequence of Trypanosoma cruzi located at the 3'-end of a poly (A) ${ }^{+}$transcript. Gene 146: 245-250.

Requena JM, Jimenez-Ruiz A, Soto M, Lopez MC, Alonso C 1992. Characterization of a highly repetitive interspersed DNA sequence of Trypanosoma cruzi: its potential use in diagnosis and strain classification. Mol Biochem Parasitol 51: 271-280.

Requena JM, Lopez MC, Alonso C 1996. Genomic Repetitive DNA Elements of Trypanosoma cruzi. Parasitol Today 12: 279-282.

Requena JM, Soto M, Alonso C 1993. Isolation of Trypanosoma cruzi specific nuclear repeated sequences. Biol Res 26: 11-18.

Rondinelli E, Moura-Neto RS, Silva R, Soares CMA, Carvalho JF, Castro FT 1986. Control of tubulin gene expression during metacyclogenesis of Trypanosoma cruzi. FEBS Letters 208:379-385.

Schijman AG, Levin MJ 1992. Nucleotides sequence of the cDNA encoding a Trypanosoma cruzi acidic ribosomal P0 protein: a novel C-terminal domain in T. cruzi ribosomal P proteins. Nucl Acids Res 20: 2894.

Sloof P, Bos JL, Konings AFJM, Menke HH, Borst P, Gutteridge WE, Leon W 1983. Characterization of satellite DNA in Trypanosoma brucei and Trypanosoma cruzi. J Mol Biol 167: 1-21.

Solari A 1980a. The 3-dimensional fine structure of the mitotic spindle in Trypanosoma cruzi. Chromosoma 78: 239-255.

Solari AJ 1980b. Function of the denses plaques during mitosis in Trypanosoma cruzi. Exp Cell Res 127: 457-460.

Solari AJ 1995. Mitosis and genome partition in Trypanosomes. Biocell 19: 65-84.

Takle GB, Cross GAM 1991. An 85-kilodalton surface antigen gene family of Trypanosoma cruzi encodes polypeptides homologous to bacterial neuraminidases. Mol Biochem Parasitol 48: 185-198.

Teixeira SMR, Russell DG, Kirchhoff LV, Donelson JE 1994. A differentially expressed gene family encoding "Amastin", a surface protein of Trypanosoma cruzi amastigotes. J Biol Chem 269: 20509-20516.

Thompson C, Dvorak JA 1989. Quantitation of total DNA per cell in an exponentially growing population using the diphenylamine reaction and flow cytometry. Analytical Biochem 177: 353-357.

Urmenyi TP, Soares MB, Bonaldo MF, Rondinelli E 1996. Trypanosoma cruzi genome project: construction of a normalized cDNA library. Mem Inst Oswaldo Cruz 91: 29. 
Van der Ploeg LHT, Liu AYC, Borst P 1984. Structure of the growing telomeres of trypanosomes. Cell 36 : 459-468.

Vasquez MP, Schijman AG, Ben-Dov C, Lorenzi H, Levin MJ 1996. Detection of polymorphism in the Trypanosoma cruzi TcP $2 \beta$ gene family by single strand conformational analysis (SSCA). Gene 180: 43-48.
Vazquez MP, Schijman AG, Levin MJ 1994. A short interspersed repetitive element provides a new 3' acceptor site for trans-splicing in certain ribosomal P2 beta protein genes of Trypanosoma cruzi. Mol Biochem Parasitol 64: 327-336.

Wagner W, So M 1990. Genomic variation of Trypanosoma cruzi: Involvement of multicopy genes. Infect Immun 58: 3217-3224. 